\title{
Social Preservation of Traditional Administration of Indigenous Peoples - The Ho Tribe in India
}

Christina Deogam ${ }^{+}$

\section{Abstract}

Indigenous peoples have distinguished cultural traditions and linguistic identity. Across the world, Indigenous peoples have always asked the State to recognise their social structure and opportunities to preserve their traditional lifestyles. The issues at stake are their rights over habitat and natural resources and the need to curtail private and public sector exploitation through alien hands. Due to the need to survive, helplessness and systematically forced assimilation, the traditional fabric of their culture are being distorted and defaced. This study deals with the concerns and issues relating to the protection of identity, tradition and customs of Ho tribe that inhabits the West Singhbhum in the State of Jharkhand in India.

Keywords: Traditional Administration; Ho Tribe; Social Preservation; West Singhbhum; Jharkhand; Munda- Manki System

\footnotetext{
${ }^{\dagger}$ Research Scholar, Department of Political Science, Faculty of Arts (Humanities), Ranchi University, Ranchi, Jharkhand, Email: deogamchristina.a@gmail.com

(C) 2020 Deogam. This is an Open Access article distributed under the terms of the Creative Commons Attribution License (http://creativecommons.org/licenses/by/2.0), which permits unrestricted use, distribution, and reproduction in any medium, provided the original work is properly cited.
} 


\section{Introduction}

Indigenous peoples are found in every corner of the world. According to the United Nations Development Programme (UNDP) the total population of indigenous people is $\mathbf{3 7 0}$ million spread across 90 countries. ${ }^{1}$ The largest continent of Asia contains $70 \%$ of the total indigenous population. Indigenous groups across the globe have diverse and distinct social, cultural, economic and political characteristics.

Worldwide, indigenous people share common problems related to their rights. Many times, indigenous people have struggled to have their lifestyles and rights to their traditional land, territory and natural resources recognised (Mankiller, 2009). The international community recognised the importance of special measures to protect indigenous people's rights and preserve their distinct culture and lifestyles.

In response to the needs of indigenous peoples, the UN General Assembly developed a minimum standard for the treatment of indigenous people. The United Nations Declaration on the Rights of Indigenous Peoples (UNDRIP) contains the minimum requirements for survival, dignity and wellbeing of indigenous people of the world (Indigenous Corporate Training Inc., 2014). Although the declaration is not legally binding it represents a signatory country's commitment to improve the wellbeing of their indigenous population and abide by the principles contained in UNDRIP (United Nations, 2020). Articles $3,{ }^{2} 4{ }^{3}$ $5^{4}$ of the UNDRIP recognises Indigenous peoples' right to self-determination and that Indigenous people have the right to choose their own political status, have own self-government and autonomous institutions and pursue economicsocial-cultural development (Hanson, 2009). These articles encourage the recognition and support of the traditional administration of Indigenous communities.

Signatory countries like Brazil, Australia, New Zealand \& some European and African countries have formed special laws for preserving tradition \& custom of indigenous people dwelling in their countries. The primary role played in conservation and preservation of tradition is by traditionalist conservatism. They emphasise the adoption of custom, convention and tradition in the administration of indigenous communities. They defend ancestral institutions which have the essence of natural laws, leadership, authority and hierarchy. An example of UNDRIP in action is the United States of America which has 573 federally recognised tribal governments. ${ }^{5}$ These ethnic groups possess the right to form their own governments, to enforce own laws (both civil and criminal) within their lands, to tax, to set up requirements for membership, to license and to regulate activities, etc. These tribes have some

\footnotetext{
${ }^{1}$ Indigenous peoples. Retrieved on 21 November 2018 from, www.undp.org/content/undp/en.home/democraticgovenance-and-peacebuliding/rule-of-law-justice-security-and-human-rights/indigenous-peoples.html

${ }^{2}$ Article 3: Indigenous peoples have the right to self - determination, by virtue of that right they freely determine their political status and freely pursue their economic, social and cultural development. United Nations Declaration on the rights of Indigenous Peoples. Retrieved on 25 February 2020 from, https://www.un.org/development/desa/indigenouspeoples/wp-

content/uploads/sites/19/2019/01/UNDRIP_E_web.pdf\&

${ }^{3}$ Article 4: Indigenous peoples, in exercising their right to self- determination, have the right to autonomy or selfgovernment in matters, as well ways and means for financing their autonomous functions. United Nations Declaration on the rights of Indigenous Peoples. Retrieved on 25 February 2020 from,

https://www.un.org/development/desa/indigenouspeoples/wp-

content/uploads/sites/19/2019/01/UNDRIP_E_web.pdf\&

${ }^{4}$ Article 5: Indigenous peoples have the right to maintain and strengthen their distinct political, legal, economic, social cultural institutions, while retaining their right to participate fully, if they so choose, in the political, economic, social and cultural life of the State. United Nations Declaration on the rights of Indigenous Peoples. Retrieved on 25 February 2020 from, https://www.un.org/development/desa/indigenouspeoples/wpcontent/uploads/sites/19/2019/01/UNDRIP_E_web.pdf\&

${ }^{5}$ Tribal Nations \& the United Nations: An introduction. Retrieved on 11 September 2018 from, www.ncal.org/abouttribes
} 
limitations, similar to states, for example, they have no power to make war, engage in foreign relations, or coin money. As seen by this example, UNDRIP has started to improve outcomes for indigenous people, but there are still concerns and issues that confront indigenous people on a daily basis that still need to be addressed. This study will discuss the issues and concerns of protection of identity, tradition and customs by exploring the customs and traditions of the Ho tribe in India.

\section{The Indian Context}

The tribal population of India, as per the 2011 census, is 104.3 million constituting $8.6 \%$ of the total population. The ethnic groups in India are termed as Scheduled Tribe and mentioned in the
Constitution of India. Article 366 (25) of the Indian Constitution defined Scheduled Tribes as "such tribes or tribal communities as are deemed under article 342 to be scheduled tribes for the purposes of this constitution". Article 342 prescribes the procedure to be followed in the matter of specification of scheduled tribes. The Indigenous people in India are known as Adivasithe collective term for the indigenous people of India. The study is a description of the social preservation of traditional administration of the Ho tribe of Jharkhand. It is to be noted here that although Ho tribe is found all over India, however, they are mainly concentrated in Jharkhand (Table 1). The methodological issues are included in the following section.

\begin{tabular}{l|l}
\hline Table 1: Population of Ho tribe in States of India & 926,000 \\
\hline Jharkhand & 80,000 \\
\hline Odisha & 41,000 \\
\hline Assam & 22,000 \\
\hline West Bengal & 800 \\
\hline Bihar & 200 \\
\hline Arunachal Pradesh & 200 \\
\hline Chhattisgarh & 100 \\
\hline Tripura & 50 \\
\hline Delhi & 30 \\
\hline Maharashtra & 20 \\
\hline Tamil Nadu & 10 \\
\hline Punjab & $1,139,000$ \\
\hline World population & \\
\hline Source: The Population of Ho peoples in different states of India. Retrieved 01 March $\mathbf{2 0 1 9}$ \\
from, http://joshuaproject.net/people_groups/16944/IN
\end{tabular}

\section{Methodology}

This research is a case study of the Ho tribe that describes them and attempts to explain the status of traditional administration in their communities. A case for social preservation is argued on the basis of primary and secondary data. For primary data, observation method and interview method has been used. One has to note that Ho tribe is highly under-researched. So, the literature used here is mainly grey literature. However, some other secondary sources include materials collected from the internet, printed books and journals. The universe of study is West Singhbhum district of
Jharkhand state of India. The data has been analytically studied and results have been drawn out.

Firstly, the study discusses the importance of social preservation. It will then describe traditional administration of Ho tribes, decision making in Ho communities and the Munda Manki system of the Ho people. Then finally describes how traditional administration is working for the Ho people of Singhbhum. The study will then present recommendations and conclusions. 


\section{Need for Social Preservation}

Many indigenous communities have contemporary traditional forms of governance that co-exist with political actors, as well as the institutions and laws of the State (Holzinger, 2016). The continual practise of traditional administration leads to conservation of traditions and customs. To protect the traditional administration as well as the lifestyles of indigenous people, society must be aware of the existence of such administration. The society also needs to acknowledge the traditions and customs of ethnic groups and that social preservation remain paramount. Social preservation encompasses the organisation of social activities in a way that maintains the values and traditions of society. It plays a vital role in maintaining the tribal identity, and it encourages the preservation of lifestyles of indigenous people and things related to them.

For this, society must get involved in the process of social preservation to save traditions and customs. Thus, social preservation can be defined as a process which engages society in activities which supports the practice of tradition, customs, values, folklore, language, rituals, etc., through writing, education, and documentation. For example, preservation can be done through books, magazines, and certain information about the lifestyles of indigenous people, establishing a museum, developing and promoting tribal research and documentation centre, library and archival, digitalisation of the rare and precious contents/materials into econtent, the establishment of tribal university at Central and State levels. The academic institution can also organise academic exercises like seminars, conferences, workshops, etc., for sharing and disseminating information about indigenous people.

The process of social preservation, if it exists, has not been successful in engaging society in the importance of preserving and maintaining societal values and traditions because of the growing gap between the traditional political system and the pace of modern governance. The case study of the Ho tribe of West Singhbhum illustrates how a traditional political system works alongside the government welfare schemes in Jharkhand.

\section{Traditional Administration of the Ho tribes}

Every ethnic group has its own self-rule system which they use for preserving their social identity. According to Crook (2005) traditional institutions are living institutions, not museum pieces. Traditional institutions have played an important role in the socio-economic-political development. The role of the traditional institutions is govern by customs and native laws (Orji \& Olali, 2010) and is under supervision of the hereditary village's chiefs. The authors further explain that the fundamental essence of the traditional institutions is to preserve the customs and traditions of the people, to maintain peace and order and solve the problem disrupting the harmony among the villagers (Orji \& Olali, 2010).

The process of traditional administration includes the selection of Ho chiefs and elders, rules and procedures for decision-making, customary law and dispute settlement, land allocation, marriage, and inheritance. The selfrule system is a traditional administration in the tribal village where the headman or chief is a leader and responsible for governance (Behera, 2005). The traditional administration governs the village consisting of ethnic groups under traditional institution and through customs and ancient laws. The traditional administration has its essence in traditional authority.

In the tribal village, the authority of an organisation or a ruling regime derives its power from tradition or custom; - this authority which is however, in the hand of chiefs and termed as traditional authority. The leaders administer society by the rules of inheritance. The administration depends on the willingness of the group's members to respect such traditional authority which governs through traditional institutions. Traditional institutions play a vital role in conserving language, cultural expressions \& heritage, craftsmanship, customary laws and norms, agricultural \& ecological knowledge, medicinal knowledge, indigenous knowledge and protection of ancestral remains. Traditional institutions also play an important role in the 
socio-economic-political development of the community.

The hierarchy of patriarchy in the Ho community reflects gender gap. The women do not participate in decision-making process. Women cannot be head of village or Manki. The rigid customary practices forbid woman to be head of village or Manki. The villages such as Tartariya, Kamharhatu, Tekrahatu, Khutpani of West Singhbhum district has acknowledged men leaders in traditional institutions since the beginning. There is no evidence of women being a leader.

The Ho tribe are closest and inclined more to the Munda-Manki system, a traditional form of administration, hence needs to be preserved. The Indian Act of Panchayats extension to scheduled areas (PESA) 1996 recognises the importance of traditional leadership as an effective tool to conserve cultural heritage and Indigenous knowledge. The PESA 1996 is a law enacted by the Government of India for ensuring self-governance through Gram Sabha. The village consisting of Ho tribe is governed by Munda - Manki system besides Gram Sabha and Panchayat system. There is a mutual working of traditional rule and modern form of governance today in the Singhbhum area.

\section{Decision Making in the Ho Communities and the Munda Manki System}

The decision-making process of the Ho tribe is based on their lifestyles, which is closely related to the land, forest and water. The Ho tribe is socially, religiously and politically wellintegrated (Srivastava, 2007). They are interconnected and interdependent with nature-human-spirit that leads them to live peacefully. According to Deuri Gurucharan Tiriya, the village priest of Tartariya, beliefs in the presence of the Creator Singhbonga, the village Goddess Kamaladevi and the protector of village, ancestral spirits. This appears similar to the observations drawn earlier by Anthropologist Vidyarthi (Srivastava, 2007).

Ho communities traditionally have a three-level decision-making process; village level, cluster level and community level. The village-level includes all the people that inhabit in the village. This is the primary unit of the traditional decision-making process, which is called a village council or Hatu dunub. In each village, there is a head/chief known as Munda. In different villages, the village cluster is known by different names in different communities. In the Ho community, it is known as Manki Pir. At the community level the Adivasi self- governing system is known by different names. In Ho tribe, the community is called Manki Sangh, and the post holder is called Manki \& Munda. The term "Munda" came from the tribal word 'Mundi', which means bando-basti or settlement of a house in the tribal habitation. The term Manki means the person who takes care of the people. Usually in the Adivasi community, the decisionmaking process is more people-centred or democratic which includes the three sections that is, Karyapalika (the Executive), Vidhayika (the Legislature), and Nyayapalika (the judiciary). They exist from the village level to the community level. The whole process is based on the collective decision-making process. Traditionally Adivasis believe that power must be distributed within the community. The village consisting of Ho people is called Hatu which is a small republic.

One significant aspect of the traditional decisionmaking process is to ensure that village administration is based on mutual consent of the people in the village. But with the passage of time, there has been a lot of change in the traditional decision-making process and governance administration. The Ho tribe like other Adivasi communities have adapted themselves with changing administration processes. The head of the village has worked according to the given conditions of the ruler. The British introduced the administration system in which the political system of the Ho tribe was recognised in the Munda-Manki system, also known as Wilkinson Rule. The political affairs were left in the hands of Munda, and Manki was responsible for the collection of tax. The postindependence era brought elected parliamentary democratic system, paving the way for elected representatives to discuss the problems of tribal community in the 
Parliament. While Jharkhand state was part of Bihar till 2000, West Singhbhum was part of East Singhbhum and was politically administrated under Bihar Panchayat Raj system.

\section{The Ho people of Singhbhum}

The Singhbhum area of Jharkhand is known through history for its autonomy movements and demand for recognition of self-governance system. West Singhbhum district has a dense population of Ho tribe. The political administration has recognised the traditional self-governance system through the provision of the PESA 1996. The Munda - Manki system of the Ho people is a self-governance system which follows their own traditions, customs and laws for administration. West Singhbhum district forms the southern part of Jharkhand. It has fifteen district blocks and three administrative sub-divisions. With the passage of time, the custom and laws have been recognised by the Government of India. The traditional administration has been merged with a modern form of governance which led to the decline of the pure form of the traditional element. There is not much documentation and information of the political system and traditional administration of the Ho tribe; hence further indepth research is needed in this area for social preservation.

After India gained independence from the British in 1947, the governance in the Ho region underwent a change by replacing the Government of India's welfare programmes in place of the village administration based on consent. This is driving them away from the conservation of their administration system. Today, Munda-Manki system works according to provisions given to them by the Central Government. The function and activities of this traditional system are limited to certain areas, and several indigenous communities are marginalised. Their living in the forest

\footnotetext{
${ }^{6}$ Article 244- Part X, Administration of Scheduled Areas and tribal areas. The Fifth Schedule is extended to administration of the Scheduled Areas and Scheduled Tribes in any state other than the states of Assam, Mizoram, Tripura \& Meghalaya. These four states come
}

ecosystem and conserving and preserving environmental resources has become a secondary priority.

Before 2000 A.D, the Bihar panchayat system focused more on non-scheduled dominated areas and neglected the scheduled areas. This imbalance led to the weakening of the traditional institutions. The Bihar government did not favour the traditional governance system. The industrialisation and urbanisation added to further exploitation of Adivasis. They became victims of oppression and suffered marginalisation and displacement, which led them to move deep into forest and hills for settlement.

States with scheduled areas were given the freedom to form its own laws with respect to traditional governance system under the PESA enacted on 24 December 1996. This act included Article 243 (243 A to 243 O) in the Constitutions which paved the way for the establishment of the panchayats institution in the scheduled areas. The PESA sought to enable the panchayat's and Gram Sabhas to implement a system of self -governance concerning a number of issues such as customary resources, minor forest produce, minor minerals, minor water, bodies, selection of beneficiaries, a section of projects and control over local institutions. The scheduled areas are those which are predominantly inhabited by the tribals, often economically backwards due to lack of opportunities and years of negligence. They need special attention of the Government to enhance their development. These areas are governed by the governor, as mentioned in Article $244^{6}$ of the Indian Constitution.

The Ho tribe comes under the "Scheduled Areas" as mentioned in the Indian Constitution. The administration of the Adivasis of Scheduled Areas comes under the Fifth Scheduled and Tribal Advisory Council $\{T A C\},{ }^{7}$ the constitutional decision-making body for

under the Sixth Schedule. Retrieved on 26 February 2020 from,

https://www.constitution.org/cons/india/p10244.html

7 Article 244(1). Provisions as to the Administration Control of Scheduled Areas and Scheduled Tribes, Fifth 
Scheduled Areas. The Fifth Schedule is one list in the Constitution of India that tabulates bureaucratic activities of the Government. The Indian Constitution has nine schedules. Under the Fifth Schedule, during the implementation of developmental projects, Free Prior Informed Consent [FPIC] is required to gain consent from affected parties. The principal of FPIC in India is to protect indigenous communities like the Ho tribe and others from unwanted encroachment and help them safeguard their lands and resources. Unfortunately, instead of gaining consent or negotiating with affected parties, in reality, only consultation is done. Further, FPIC includes mostly men; women are left out from the decision-making process. The affected parties are just informed of development projects planned to be implemented, instead of the getting permission of the people who are going to be affected.

In Jharkhand, the traditional self-governance system of Ho tribe exists but, in many places, it is on the verge of extinction. For active participation in politics and to have a political party consisting of the Adivasi population is challenging. The Adivasi political party is easily dominated by non Adivasi political party which weakens the Adivasi interests. Today, there are tribal welfare-oriented political parties consisting of members from both Adivasi communities and non-Adivasi communities. Because of the domination of non-tribal, there are problems related to self-governance process in the Ho tribe. For example, the self-governance administration of the Ho tribe is yet to get recognition and acceptance by the State. The union government and state government of Jharkhand do not take advice or consent from Indigenous people in legislative matters. The representative of the scheduled area fails to draw attention to problems of one's constituency because the representative now gets involved in the activities of parties to which he/she belongs.

Schedule. Retrieved on 01 July 2019 from, http://www.mea.gov.in/images/pdf1/S5.pdf

${ }^{8}$ Fresh calls for separate Kolhan nation' keep Jharkhand government on toes (2017, 24 December). New Indian
The active participation of Indigenous people in the decision-making process helps in conservation and protection of natural resources, reduction of deforestation, promotion of indigenous knowledge system, preservation of their distinct socio-cultural and economic development. Indigenous people's participation in the decision-making process also contributes to the education system according the indigenous system. But as Indigenous people are not involved in the decision-making process there has been a negative impact on conservation of cultural-tradition-socioeconomic ethos. Though the terms of PESA authorised the traditional management practices of community resources and judgments of cases according to customary laws, the state legislation of Jharkhand Panchayati Raj Act has accepted it in a restricted form. There has been an ongoing Kolhan movement in this area. Due to this, the Singhbhum area is also known as the Kolhan region where tribal leaders have demanded autonomous Kolhan country, separating themselves from India. The organised campaigns for the Ho tribe date back to the late 1970s. The reason which enraged the separatists to demand for autonomous nation was continued repression of the tribal people by nontribal and erosion of the Kolhan tribals' traditional village administration system of Manki-Munda, which has existed for generations. $^{8}$

\section{Recommendations}

The Ho community, as well as other indigenous communities, face a future where modern values clash with traditional values. It is a complex problem that cannot be solved just by being a signatory to UNDRIP. Countries that have signed up have committed to move in certain directions and abide by the principles that assist them in combating discrimination and marginalisation of indigenous people. Governments not only need to put rules and regulations in place but also continually adopt

Express. Retrieved on 25 December 2017 from, www.newindianexpress.com/thesundaystandard/2017/d ec/fresh-calss-for-separete-kolhan-nation-keepJharkhand_government-on-toes-1735518.html 
independent reviews to make sure that proper procedures are being adhered to. For example, in the case of the Ho community, reviewing project decisions to see if FPIC has been obtained rather than decisions being made for them.

Social preservation and cultural preservation are important for the protection of values of ethnic groups like the Ho tribe. Due to industrialisation, globalisation and marginalisation of ethnic group's traditional administration are on the verge of disappearing. The act of preservation of traditions is necessary for the protection of tribal identity. Social preservation demands the responsibility of the members of society. Community participation is encouraged to involve them in activities which promote conservation of tradition. The dialogue between the members of the community helps preserve and strengthen customs and tradition. The tradition gives a sense of belonging and shapes the structure of family and society. Seminars, conferences and workshops are other examples of collective dialogue necessary for social preservation. In India, there is a Ho tribe association in Orissa, Jharkhand, Mumbai, and Delhi. These associations publish a magazine annually, the Areshi. These associations play a major role in preserving tradition but they focus more on culture. Their focus on the political system needs to be improved. Every educational institution can play a significant role in preserving information about different indigenous people and their language in the curriculum.

The process of institutionalisation can play an important role in preservation. Institutionalisation means a place where teacher and student can interact and learn tradition and culture. The institution like tribal university, Agartala can be run by the Government or NonGovernmental Organisations or any private organisations. Another feasible option is the recognition of artists who have knowledge of tribal song and dances, and arts and crafts.

\footnotetext{
${ }^{9}$ Aiyesha, A. (2017, 17 January). Preservation of heritage and tribal culture. Retrieved on 15 September 2018 from,
}

Recognition will improve the motivation of the artists to carry out their practice with more enthusiasm. Awareness programmes can do preservation in tribal society through various modes and it could equip people with tradition, and they can practise it. There should be tradition exhibition, tradition exchange, and archival of tradition. The documentation of cultural and traditional practices are important. The documentation can be done in written form, photographic form, and digital form. Human documentation by conducting training programmes, involving traditional scholars and by institutionalising the traditional learning. ${ }^{9}$

\section{Conclusion}

The problem faced by the Ho community is similar to other ethnic communities in the world. The problem in the tribal area can be solved only by the rule of traditional administration as tribal people are closer to it in comparison to the authoritarian top-down approach of governance. The traditional Government and modern Government have to walk together to bring grassroots development. The social preservation and cultural preservation of indigenous people is an utmost factor in the process of development and protection of their ancient ethics and values. Preservation of tradition and customary laws of $\mathrm{Ho}$ is inseparable from advancing research for their cause including efforts to set up a museum, tribal research centre, and promotion of traditional practices and art.

\section{References}

Aiyesha, A. (2017, 17 January). Preservation of heritage and tribal culture. Retrieved on 15 September 2018 from, http://www.slideahare.net/mobile/meakham15 /0-preservation-of-heritage-and-tribal-culture.

Behera, P. (2015). Understanding the concept of tribal self-rules in Jharkhand, India. Indian Journal of Dalit and Tribal Studies and Action, 3(2), 88-105. Retrieved on 22 November 2018 from,

http://www.slideahare.net/mobile/meakham15/0preservation-of-heritage-and-tribal-culture. 
http://www.ticijournals.org/understanding-theconcept-of-tribal-self-rule-in-jharkhand-india

Crook, R. (2005). The role of traditional institutions in political change and development, CDD/ODI Policy Brief No. 4. Retrieved on 04 September 2019 from, https://www.odi.org/resources

Hanson, E. (2009). UN declaration on the rights of Indigenous Peoples. Indigenous foundations.arts.ubc.ca. Retrieved on 23 December 2019 from, http://indigenousfoundations.arts.ubc.ca/un_d eclaration_on_the_rights_of_indigenous_peopl es/

Holzinger, K., Kern, F. G., \& Kromrey, D. (2016). The Dualism of Contemporary Traditional Governance and the State: Institutional Setups and Political Consequences. Political Research Quarterly, 69(3), 469-481. https://doi.org/10.1177/1065912916648013

Indigenous corporate training inc. (2014). Working effectively with indigenous peoples blog. UN declaration on the rights of indigenous peoples. Retrieved on 23 December 2019 from, https://www.ictinc.ca/united-nationsdeclaration-on-the-rights-of-indigenouspeoples-snapshot

Joshua project (2020). Ho in India. Retrieved on 20 January 2020 from, http://www.joshuaproject.net/people_groups/ 16944/IN

Mankiller, W. (2009). Being indigenous in the 21st century. Cultural Survival Quarterly Magazine, 33(1A). Retrieved on 10 September 2018 from, http://www.culturalsurvival.org/publications/c ultural-survival-quarterly/being-indegenous21st-century.

Orji, K. \& Olali, S. (2010). Traditional Institutions and their Dwindling Roles in contemporary Nigeria: the rivers state example. In T. Babawale, A. Aloa \& B. Adesoji, (eds.) The Chieftaincy Institution in Nigeria, Lagos: Concept Publication Ltd.

Srivastava, M. (2007). The Sacred Complex of Munda Tribe, The Anthropologist, 9(4), pp 327330, DOI: 10.1080/09720073.2007.11891020

United Nations Development Program (2018). Indigenous peoples. Retrieved on 21 November 2018

from,https://www.undp.org/content/undp/en/ home/2030-agenda-for-sustainabledevelopment/peace/governance/indigenouspeoples.html

United Nations (2020). Declaration on the Rights of Indigenous Peoples: Frequently Asked Questions. Retrieved on 27 September 2019 from,

https://www.un.org/esa/socdev/unpfii/docume nts/faq_drips_en.pdf

\section{Acknowledgements}

I am thankful to Dr. Emmanuel Barla, Principal of St. Xavier's College, Ranchi for guidance and Dr. Venkat Pulla, Mr Bharath Bhushan Mamidi, Sociologist, Hyderabad and the anonymous reviewers for their suggestions to improve this article. I am also thankful to my friends Prity Dolly Aind, Anjali Toppo and Abhijit Vincent Toppo for assisting me in completing this article. Lastly not the least I am grateful to Elizabeth Carter, Research Associate at write.assist.service@gmail.com for her pro bono assistance in this instance. 